The Humanity of Thucydides 



\section{The Humanity of Thucydides}

\section{Clifford Orwin}

PRINCETON UNIVERSITY PRESS

PRINCETON, NEW JERSEY 
Copyright (C) 1994 by Princeton University Press Published by Princeton University Press, 41 William Street,

Princeton, New Jersey 08540

In the United Kingdom: Princeton University Press, Chichester, West Sussex

All Rights Reserved

Library of Congress Cataloging-in-Publication Data

Orwin, Clifford, 1947-

The humanity of Thucydides / Clifford Orwin. p. $\mathrm{cm}$.

Includes bibliographical references and index.

ISBN 0-691-03449-4

ISBN 0-691-01726-3 (pbk.)

1. Thucydides. History of the Peloponnesian War. 2. Greece-

History-Peloponnesian War, 431-404 в.c.-Causes.

3. Human behavior. I. Title.

DF229.T607 $1994 \quad 938^{\prime} .05-\mathrm{dc} 20 \quad 94-3111$

This book has been composed in Galliard

Princeton University Press books are printed on acid-free paper and meet the guidelines for permanence and durability of the

Committee on Production Guidelines for Book Longevity

of the Council on Library Resources

Third printing, and first paperback printing, 1997

Printed in the United States of America

357910864 
To my parents 
